\title{
国 \\ The Earnings Management Motivation: Accrual Accounting vs. Cash Accounting
}

\author{
Sandeep Goel ${ }^{1}$
}

\begin{abstract}
The Accrual basis of accounting has always found favour amongst corporate practitioners of earnings management. There have been extensive studies on earnings management, focusing on earnings hazards. This paper contributes to the literature by showing market inclination to accrual basis of accounting as motivated by a desire for earnings management. It analyzes the sample units' performance in regard to accrual-indicators vs. cash-indicators and their pervasiveness on stock pricing in India. In India, the corporate ownership model is the Promoter Dominated Shareholders Model (PDSHM) which makes this study unique in highlighting earnings management motivation. The units show a market preference for accrual numbers and motivation for earnings management as clear in their stock pricing behavior. I hope the study improves investors' perception of the reliability of a firm's performance, as measured by earnings. It is of use to the users of financial accounting and corporate finance globally for rationalizing the motivation behind earnings manipulation by the management.
\end{abstract}

\section{JEL Classification: M41}

Keywords: Accrual basis, cash basis, accounting indicators, stock pricing, earnings management

\footnotetext{
${ }^{1}$ Management Development Institute, Gurgaon, India
} 


\section{Introduction}

The purpose of financial statements is always to report to the various stakeholders to help the management's performance evaluation. This is where the accrual system of accounting assumes high importance. It is considered superior to others though it has been constantly challenged by cash-flow accounting. The challenge by cash-flow accounting is more on the importance and efficacy of accrual accounting and a shift toward the cash flow approaches in security analysis (Hawkins \& Campbell, 1978). The question about the superiority of accrual accounting over cash-flow accounting is concerned with the objectives and the nature of financial reporting, i.e. the accrual system of accounting is preferred for its objective of Earnings management. That said, earnings management is a strategy that can be used by the management of a company to deliberately manipulate the company's earnings to meet a pre-determined target. This practice is carried out with the help of accrual accounting. Goel's (2012) study evaluates the implications of discretionary accruals for earnings management in the Indian corporate enterprises. His analysis indicates the presence of accrual related earnings management in the units studied.

Thus, the main objective of this discussion is to examine empirically the relative merits of accounting indicators from both accrual and cash-flow accounting in terms of their persistence and variability for stock behaviour with regard to earnings management.

India saw two large corporate scams namely Satyam and Kingfisher in 2009 and 2012 respectively. It not only led to financial loss for the shareholders but also disturbed the status quo of the entire financial system. Incidence of any such scam opens up to question the effectiveness of the governance framework and the quality of reported earnings. It requires a change in the regulatory regime. India had its transformation process in the form of new Companies Act, 2013 after a gap of 57 year since old Companies Act, 1956. This will act as a reference point globally and is the key to this study's relevance.

In the US there is a shareholder model of corporate governance. Countries like Japan have a coordinated model. But, in India companies witness Promoter Dominated Shareholders Model (PDSHM) with strong control of promoters. In the private sector, most of the companies are family-owned businesses with largest shareholder holding over 50\%. This calls for a special attention to the motivation of earnings management and its detection at an early stage.

However, there have been limited studies which explored the quality of earnings in the Indian context. This study evaluates the quality of reported earnings of Indian companies operating globally. The policy makers in India have amended clause 49 of Listing Agreement to inculcate sound governance practices among Indian corporate. This makes the present study important and timely. Also, a recent study by (Pathak et al., 2014) stresses that each country has 'its own standards, regulations and culture', and there is a need to explore earnings management - in that specific context.

The paper contributes to the literature by studying the market response to the basis of accounting for detecting earnings management in Indian companies. This effect has been examined with the help of accounting indicators in the selected corporate enterprises. Further, their variability and persistence have been checked to test the degree of earnings management evidences. 
The rest of the paper is organised as follows. Next section presents a detailed literature review of related concepts for developing our predictions about earnings management. Subsequent section explains the sample selection procedure, research methodology and descriptive statistics. Section 4 presents the results of the analysis with section 5 concluding the paper. Section 6 and 7 present the limitations of the study and implications for future research.

\section{Literature Review}

\section{Definitions of earnings management}

Earnings management by companies has long been documented in the academic literature. Management of reported earnings is a major accounting concern both for academia as well as industry (Dechow \& Skinner, 2000).

Watts and Zimmerman (1978) state that earnings management occurs when managers have a discretionary behaviour related to accounting numbers with or without limits and this behaviour can be adopted to maximize the value of the company. Many surveys have been published on the topic (Barnea etal.,1976; Imhoff,1977; Ronen \& Sadan,1981; Healy \& Whalen, 1999; Dechow \& Skinner, 2000; Stolowy \& Breton, 2004). (Shipper, 1989) says that earnings management is " . . a purposeful intervention in the external financial reporting process, with the intent of obtaining some private gain . .." (Healy \& Whalen, 1999, p.368) explain that earnings management occurs when managers use discretion to manipulate financial information ". . . to either mislead some stakeholders about the underlying economic performance of the company or to influence contractual outcomes that depend on reported accounting numbers."

In this line, García Lara et al. (2005) prove that earnings management is an intentionally carried out management practice, opportunistic and/or educational, with the purpose to report desired results, distinct from the real ones. Scott (2009) determines earnings management as "the choice of accounting policies or actions that can affect earnings to achieve a specific objective."

Consistent among these definitions is the notion of intentional manipulation of reported numbers by management. In a nutshell, Earnings management is 'accrual management', i.e. use of accruals to achieve a pre-determined target.

\section{Motivations of earnings management}

(Burgstahler etal., 1997) provide systematic evidence that firms increase reported earnings to achieve various incentives. The widespread use of accounting information by investors and financial analysts to help value stocks can create an incentive for managers to manipulate earnings in an attempt to influence short-term stock price performance. The question arises - Do firms manage earnings for stock market purposes? (DeAngelo, 1988) reports that earnings information is important for valuations in management buyouts and hypothesizes those managers of buyout firms have an incentive to "understate" earnings.

The findings show that firms report positive (income-increasing) unexpected accruals prior to seasoned equity offers (Teoh, Welch, \& Wong 1998b), initial public offers 
(Teoh, Welch, \&Wong 1998a, Teoh, Wong, \& Rao 1998).Other Prior studies on accrual earnings management (AEM) around US IPOs provided mixed results (DuCharme, Malatesta, \& Sefcik, 2001; Darrough \& Rangan, 2005; Ball \& Shivakumar, 2008; Billing \& Lewis, 2010).

Overall, the wealth of evidence on the stock-market effect of earnings numbers clearly indicates that, despite concerns about earnings management, investors view earnings as value-relevant data that is more informative than cash flow data. This finding has been replicated over long periods of time and in many countries. It suggests that investors do not view earnings management as so pervasive as to make earnings data unreliable. This interpretation is confirmed by Dechow's (1994) findings that current earnings are better predictors of future cash flows than are current cash flows.

Earnings management's link with insider trading is documented by (Beneish\& Vargus, 2002), (Park \& Park, 004) and (Cheng \& Warfield, 2005). Other studies document the relationship between earnings management and stock compensation through stock options (Baker et al, 2003), (Bartov\& Mohanram, 2004), (Kwon \&Yin, 2006).

(Graham et al., 2005) argued that managers preferred real earnings management to accrual-based earnings management because accrual manipulation was more likely to be scrutinized by external auditors and regulatory bodies while real activities manipulation had a lower chance of being detected. Moreover, (Cohen, Dey, \& Lys, 2008) found that companies switched from accrual-based to real earnings management after the passage of Sarbanes-Oxley Act (SOX) in 2002.

Recent literature suggests that possible earnings management strategies at the time of SEO issuance and in other settings are not just limited to overstatement of accruals, but can include manipulation of real activities (Cohen \& Zarowin, 2010, Zang, 2011, Badertscher, 2011).

Furthermore, research avenue in earnings management is the investigation of the drivers for the choice of one practice over the other and to explain the reason such as an IPO or financial distress situations (Cohenet al.,2008; Campa \& Camacho-Miñano, 2015).

\section{Methods of earnings management}

In earnings management, the issue of measuring the effects of managers' use of accounting discretion in accounting method choices is inevitable. There are two techniques commonly recognised to manipulate earnings: accrual manipulation or real activity manipulation (Schipper, 1989). Teoh, Wong, and Rao (1998) check depreciation estimates and bad debt provisions surrounding initial public offers. They find that, on a matched sample of non-IPO firms, sample firms are more likely to have income-increasing depreciation policies and bad debt allowances in the IPO year and for several later years. Beneish (2001) discussed the analytics for incomeincreasing earnings management, income-decreasing earnings management and specific contexts, e.g. financial institutions with regulatory constraints.

(Cohen \& Zarowin, 2010) focuses on three issues: whether managers manipulate earnings via both accruals and real activities; how firms' tradeoff between accrual and real earnings management, and the economic consequences of accrual and real earnings management 
around SEOs. The results show that firms use both AEM and REM around SEOs, and these firms outperform their industry peers in the period prior to SEOs and underperform their peers following SEOs.

(Zang, 2011) proposes that the relative extent to which managers engage in real activities manipulation versus accruals manipulation reflects the costs associated with either strategy.

The research focused on accrual manipulation represents the most significant part in earlier literature. The studies have mainly used accruals manipulation as a proxy for earnings management, total accruals can be split across discretionary and nondiscretionary accruals in the models most frequently proposed by earlier research (i.e. Healy, 1985; DeAngelo, 1986;Jones, 1991; Dechow et al.,1995; Kothari, Leone \& Wasley, 2005).

Even though, the aggregate accrual models have been widely criticised (i.e. Kothari et al., 2005; Ibrahim, 2009), and even though they have some limitations, they still remain the most used by researchers in this area (Ibrahim, 2009).

\section{Gap areas}

These review articles focused mainly on accounting choices, in the form of accruals, exercised by the management for designing earnings. Overall, there is remarkably little evidence on earnings management for motivational reasons, suggesting that this is a fruitful area for future research. As mentioned in the introductory part, the present study examines the effect of accounting indicators on stock pricing and finds out the motivation for earnings management to investigate and test timely.

\section{Research Design}

\section{Hypothesis}

The implied hypothesis is that the accounting data is derived from either an accrual accounting system or a cash-flow accounting system.

The accounting indicator most favored by the market and/or reflected in the market price will show less variability and a higher persistence than the other numbers. The rationale is that the nature of the association between the derived accounting numbers and the behavior of security prices indicates which method the market perceives to be the most related to the information used in setting equilibrium prices.

So, the method that produces accounting numbers having the association with security prices, with the least variability and the highest persistence, is the most consistent with the information that results in an efficient determination of security prices. Thus, hypothesis for the present discussion is:

\section{$\mathrm{Ha}_{\mathrm{a}}$ - The accounting indicator derived from accrual system is most favored by the market.}

The evidence on the nature of the association is also essential regardless of the efficiency of the market. It is an important factor in any accounting policy regardless of the nature of the policymakers' views about other issues, including market efficiency. 


\section{Objective of the study}

The study specifically aims at the following:

- To examine the relative merits of accounting indicators derived from either an accrual or cash-flow accounting system in terms of variability and persistence to stock prices, and

- To test the motivation for accrual behaviour and highlight the existence of earnings management in these undertakings for necessary regulation.

\section{Research methodology of the study}

Following research methodology is used in the present study.

\section{Sample Design \& Approach}

The present study covers the private listed companies in India, excluding the government undertakings and banks \& financial institutions because of their distinct regulatory mechanism. The enterprises have been chosen by their performance in terms of profit generation (PAT performance) for the year 2007-08 as per ET October, 2007 Survey, on select basis. Two criteria were used for the selection of the companies in the final sample. First, the enterprises should be in the private sector. Second, its accounting and market data, both were available for the study. Out of top twenty five corporate enterprises which were considered for the sample, only twelve met the sampling need. They contribute a significant part of India's market size and are constituent of BSE's Sensex like Dow Jones of NYSE. Therefore, 'case based' research approach has been followed here. A list of these companies appears in Appendix I.

\section{Period of the Study}

The period to be covered in the present research study is of five years, ranging from 200304 to 2007-08. It has been taken as:

(a) it is meaningful to focus the attention on earnings management practices of the enterprises chosen and detect the various grey areas with regard to accruals management, around global recession.

(b) further, a five year period is enough to show the short-term and long-term changes and let the valid conclusions.

\section{Data Used}

For the purpose of the present study, the main data used is secondary in nature keeping in the nature of the study. The study employs both accounting and market data. The accounting data was obtained from the annual reports of the units and other such records for the relevant period. Market data for the units was obtained from the BSE site.

\section{Tools / Techniques Used}

Earnings management indices, developed specifically for detecting the accrual motivation in the context of earnings management, have been used in the present study. 


\section{Accounting Indices}

The three semi accounting indices of rate of return are used for a comparison of the relative merits of accrual and cash accounting.

a. A cash-flow per share/stock price ratio is used to represent the cash accounting- derived semi accounting index of rate of return.

b. A common equity per share/stock price ratio is used to represent the accrual accounting- derived and balance sheet-oriented semi accounting index of rate of return.

c. An earnings per share/stock price ratio is used to represent the accrual accounting- derived and income statement-oriented semi accounting index of rate of return.

The cash flow per share/stock price of security $i$ for time period $t$, is defined as:

$$
\mathrm{CFP}_{\mathrm{i}, \mathrm{t}}=\frac{\mathrm{CFO}_{\mathrm{i}, \mathrm{t}} / \mathrm{CSO}_{\mathrm{i}, \mathrm{t}}}{\mathrm{P}_{\mathrm{i}, \mathrm{t}}}
$$

where,

$\mathrm{P}_{\mathrm{i}, \mathrm{t}}=$ Price oı securıy $ı$ aı ııe enu uı perıuu $\iota$ aujusted for capital changes such as stock splits and stock dividends.

$\mathrm{CFO}_{\mathrm{i}, \mathrm{t}}=$ Cash flows from operations calculated by adjusting net income for non cash charges (credits) and for changes in the current accounts, of firm $\mathrm{i}$ in period $\mathrm{t}$.

$\mathrm{CSO}_{\mathrm{i}, \mathrm{t}}=$ Common shares outstanding of firm $\mathrm{i}$ in period $\mathrm{t}$.

The common equity per share/stock price of security i for time period $t$ is defined as:

$\mathrm{CEP}_{\mathrm{i}, \mathrm{t}}=\frac{\mathrm{CE}_{\mathrm{i}, \mathrm{t}} / \mathrm{CSO}_{\mathrm{i}, \mathrm{t}}}{\mathrm{P}_{\mathrm{i}, \mathrm{t}}}$

where,

$\mathrm{CEP}_{\mathrm{i}, \mathrm{t}}=$ Common equity of company $\mathrm{i}$ at the end of period $\mathrm{t}$. Common equity represents common stock plus retained earnings.

The earnings per share/stock price of security i for time period $t$, is defined as:

$\mathrm{EPSP}_{\mathrm{i}, \mathrm{t}}=\frac{\mathrm{EPS}_{\mathrm{i}, \mathrm{t}}}{\mathrm{P}_{\mathrm{i}, \mathrm{t}}}$

where,

$\mathrm{EPS}_{\mathrm{i}, \mathrm{t}}=$ Earnings per share (primary), excluding extraordinary items, of company i for period $t$.

EPS represents the primary earnings per share figure as reported by the company.

Each of these numbers, CFPi,t, $\mathrm{CEP}_{\mathrm{i}, \mathrm{t}}$ and EPSP $\mathrm{i}, \mathrm{t}$ represents numbers that are derived from either an accrual or a cash-flow accounting system and related to the stock price and whose merits will be evaluated in terms of variability and persistence. They represent semi accounting indices of rate of return derived from either an accrual or a cash-flow accounting system (Barley\& Levy, 1979, p. 307).

The accounting indicators derived from an accrual accounting system included both a 
balance sheet-oriented number and an income statement-oriented number. The indicators also had two basic characteristics. First, they are computed as per share numbers, and second, they are ratios whose dominator is the market price of a share. The first characteristic is used to check comparison between the indicators and the companies. The second characteristic is used to ensure that the indicator reflects both accounting-based performance and market-based numbers. A second argument for dividing the accountingbased datum by the market price of a share reflects the belief that the accounting datum should be evaluated in terms of the impact on its relationships to the market price.

\section{Statistical Tools}

Statistical tools have been used for testing the results, including correlation analysis Spearman's Rank correlation coefficient, bar charts, graphs (time series), and descriptive statistics.

\section{Results and Discussion}

\section{Variability of the Derived Accounting Indicators}

The three accounting indicators, namely, the cash flow per share/stock price (CFP), the common equity per share/stock price (CEP), and the earnings per share/stock price (EPSP), were computed for the sample companies for the years 2003-04 to 2007-08. These indices of rate of return are used for a comparison of the relative merits of accrual and cash accounting.

The means, standard deviation, and coefficients of variation of these numbers are presented in Table 1 and figure 1. In addition, this table includes a ranking of the coefficients of variations of the derived accounting indicator numbers.

Table 1

CEP, EPSP, and CFP's Means, Standard Deviations, and Coefficients of Variation for the Sample Companies, 2003-04 to 2007-08

\begin{tabular}{|l|l|l|l|l|l|l|l|l|l|l|l|l|}
\hline & \multicolumn{4}{|c}{ CEPi } & \multicolumn{4}{c|}{ EPSP } & \multicolumn{4}{c|}{ CFPi } \\
\hline Co. & Mean & S.D. & C.V. & R & Mean & S.D. & C.V. & R & Mean & S.D. & C.V. & R \\
\hline RIL & 0.40 & 0.11 & 27.75 & 9 & 0.07 & 0.02 & 28.56 & 6 & 0.12 & 0.07 & 55.76 & 5 \\
\hline Sterlite & 0.30 & 0.12 & 40.82 & 3 & 0.03 & 0.02 & 62.47 & 1 & 0.01 & 0.05 & 523.07 & 1 \\
\hline TCS & 0.08 & 0.04 & 51.66 & 2 & 0.04 & 0.01 & 36.42 & 5 & 0.03 & 0.01 & 31.45 & 10 \\
\hline Tata Steel & 0.41 & 0.12 & 29.16 & 7 & 0.13 & 0.03 & 21.22 & 12 & 0.16 & 0.04 & 24.07 & 11 \\
\hline Bharti Airtel & 0.12 & 0.04 & 29.32 & 6 & 0.03 & 0.01 & 59.80 & 2 & 0.05 & 0.03 & 58.70 & 3 \\
\hline Infosys & 0.11 & 0.03 & 30.96 & 5 & 0.04 & 0.01 & 27.30 & 8 & 0.04 & 0.01 & 35.03 & 9 \\
\hline Wipro & 0.12 & 0.04 & 33.17 & 4 & 0.03 & 0.01 & 26.89 & 9 & 0.03 & 0.01 & 35.67 & 8 \\
\hline ITC & 0.19 & 0.05 & 27.95 & 8 & 0.05 & 0.01 & 25.48 & 10 & 0.05 & 0.02 & 41.20 & 7 \\
\hline Hindalco & 0.67 & 0.17 & 25.04 & 11 & 0.12 & 0.05 & 39.02 & 4 & 0.12 & 0.07 & 56.88 & 4 \\
\hline L\&T & 0.20 & 0.12 & 58.31 & 1 & 0.05 & 0.03 & 54.20 & 3 & 0.03 & 0.02 & 51.26 & 6 \\
\hline Tata Motors & 0.24 & 0.06 & 26.74 & 10 & 0.07 & 0.02 & 28.06 & 7 & 0.11 & 0.10 & 86.42 & 2 \\
\hline Grasim & 0.34 & 0.05 & 14.18 & 12 & 0.07 & 0.02 & 21.89 & 11 & 0.09 & 0.02 & 19.87 & 12 \\
\hline
\end{tabular}

Notes: 1.S.D. stands for standard deviation.

2. $\mathrm{R}$ stands for ranking 


\section{Figure 1}

Variability of Accounting Indicators for the Sample Companies, 2003-04 to 2007-08

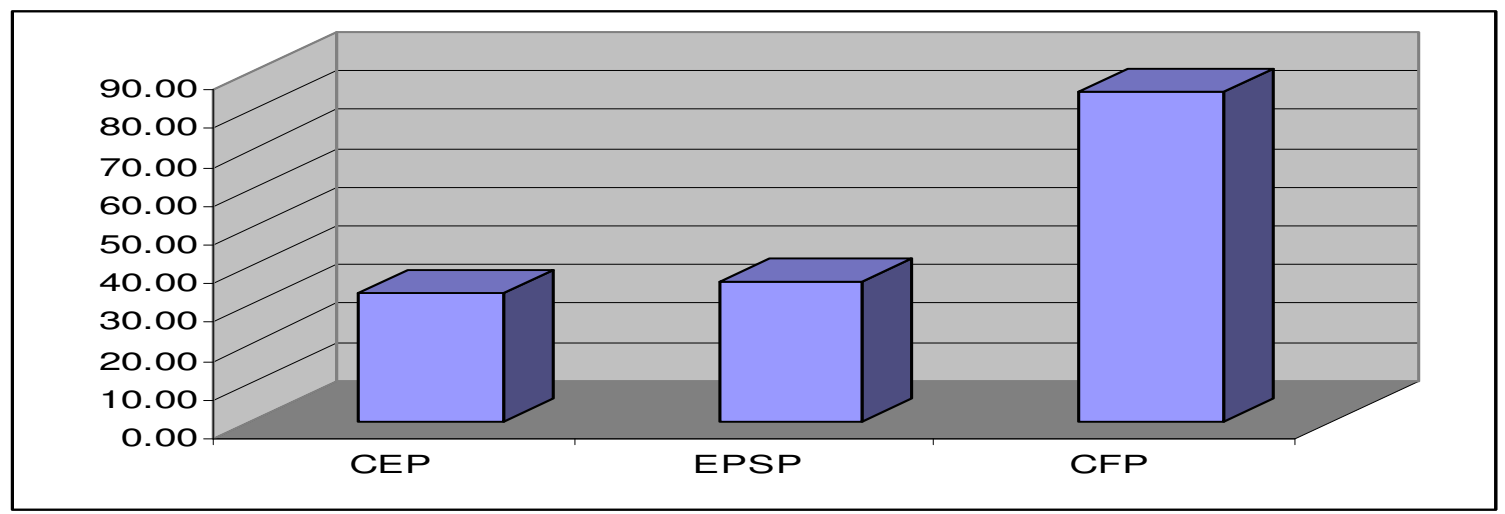

Note: CEP, EPSP and CFP denote average coefficient of variation here.

An examination of Table 1 shows a definite difference in the variability of these numbers. The variability of the CFP numbers exceeds the variability of the CEP and EPSP numbers. More precisely, the coefficients of variation of the CFP's numbers are higher than those of the CEP and EPSP numbers in seven cases .The coefficients of variation of the CEP numbers were higher than those of the EPSP and CFP numbers in three cases. The coefficients of variation of the EPSP numbers were higher than those of the CEP and CFP numbers in only two cases. Those differences are, in most cases, prominent.

For those cases where the variability of CEP and EPSP numbers exceeds those of the CFP numbers, the differences are either small or do not show any specific pattern. The variability of the CFP numbers, as measured by their coefficients of variation, ranges from a high of 523.07 for Sterlite Industries to a low of 19.87 for Grasim Industries. The main reason for such high variation in Sterlite can be attributed to negative CFP in 200405 and 2006-07. If we exclude Sterlite's variability in total CFP coefficient, even then CFP's total variability is still the highest at 41.36 among all three variables.

The average variability of the CEP is 32.92 and EPSP's is 35.94 . The variability of the CEP numbers ranges from a high of 58.31 for L\&T to a low of 14.18 for Grasim. Finally, the variability of the EPSP numbers ranges from a high of 62.47 for Sterlite to a low of 21.22 for Tata Steel.

So, the variability of CFP number exceeds the variability of CEP and EPSP numbers, both in degree and the number of companies. It indicates low market preference for cashbased indicators.

Next, the relationship between the distributions of the CEP, EPSP and CFP variables was examined by computing Spearman's rank order correlation coefficient between these distributions. The computed correlation between CEP and EPSP variables is equal to 0.76 which is significant at 0.01. Also, the computed correlation between CEP and CFP variables is equal to 0.68 which is significant at 0.05 . Finally, the computed correlation coefficient between EPSP and CFP variables is equal to 0.85 which is significant at 0.01 level. Thus, it may be concluded that in spite of the differences in the variability of EPSP, CEP, and CFP numbers, there is some correlation between them. This relationship becomes considerable for pricing issues. 
The main question created by these results refers to the possible reason(s) that the variability of cash accounting-based numbers (CFP) exceeds for a large number of firms in the sample those of the income statement-oriented numbers (EPSP) and the balance sheetoriented numbers (CEP). In other words, cash based indicators have shown more variability than accrual based indicators. This indicates market preferences for accrual based indicators in stock pricing.

One reason may stem from the fact that EPSP numbers show the earning potential of the company and are based on accounting data, which are more likely an object of discretionary accounting income smoothing, and of the smoothing process inherent in the very definition of accounting income. It may be stated first that the income smoothing is easier and more lucrative with income figures than cash-flow accounting data, and second, that managers may have a greater incentive in smoothing income figures given the stronger links between accounting income and the firm's reward structure. As a result, the market is reflecting a "high reported" income figure which might be different from the "actual" one, which may explain the variability of cash flow- based numbers.

A second reason may be that the market, is attaching more importance to the balance sheet position after income statement and then cash flow. The superiority of the balance sheet over cash-flow data may be due to a selective market response either due to the higher familiarity with balance sheet data than cash-flow data or basically due to a balance sheet fixation and a stronger interest in the financial position of the firms.

\section{Persistency of Derived Accounting Indicators}

The persistency of the derived accounting indicator numbers was determined by examining the median rank correlation between the accounting indicator number in the year of formation and the same number in later years. Table 2 and figure 2 and Tables 1 , 2 and 3 in Appendix II show consecutively the median rank correlation of all the sample companies' CEP, EPSP and CFP with the CEP, EPSP and CFP in later years.

Table 2

Median Correlation of Accounting Indices of Sample Companies, 2003-04 to 2007-08

\begin{tabular}{|l|c|c|c|c|c|}
\hline & $\mathbf{2 0 0 3 - 0 4}$ & $\mathbf{2 0 0 4 - 0 5}$ & $\mathbf{2 0 0 5 - 0 6}$ & $\mathbf{2 0 0 6 - 0 7}$ & $\mathbf{2 0 0 7 - 0 8}$ \\
\hline $\begin{array}{l}\text { CEP with CEP } \\
\text { in subsequent years }\end{array}$ & 1.00 & 1.00 & 1.00 & 1.00 & 0.70 \\
\hline $\begin{array}{l}\text { EPSP with EPSP } \\
\text { in subsequent years }\end{array}$ & 1.00 & 1.00 & 1.00 & 1.00 & 0.50 \\
\hline $\begin{array}{l}\text { CFP with CFP } \\
\text { in subsequent years }\end{array}$ & 1.00 & 1.00 & 0.41 & 0.71 & 0.58 \\
\hline
\end{tabular}




\section{Figure 2}

Persistency of Accounting Indices of Sample Companies, 2003-04 to 2007-08

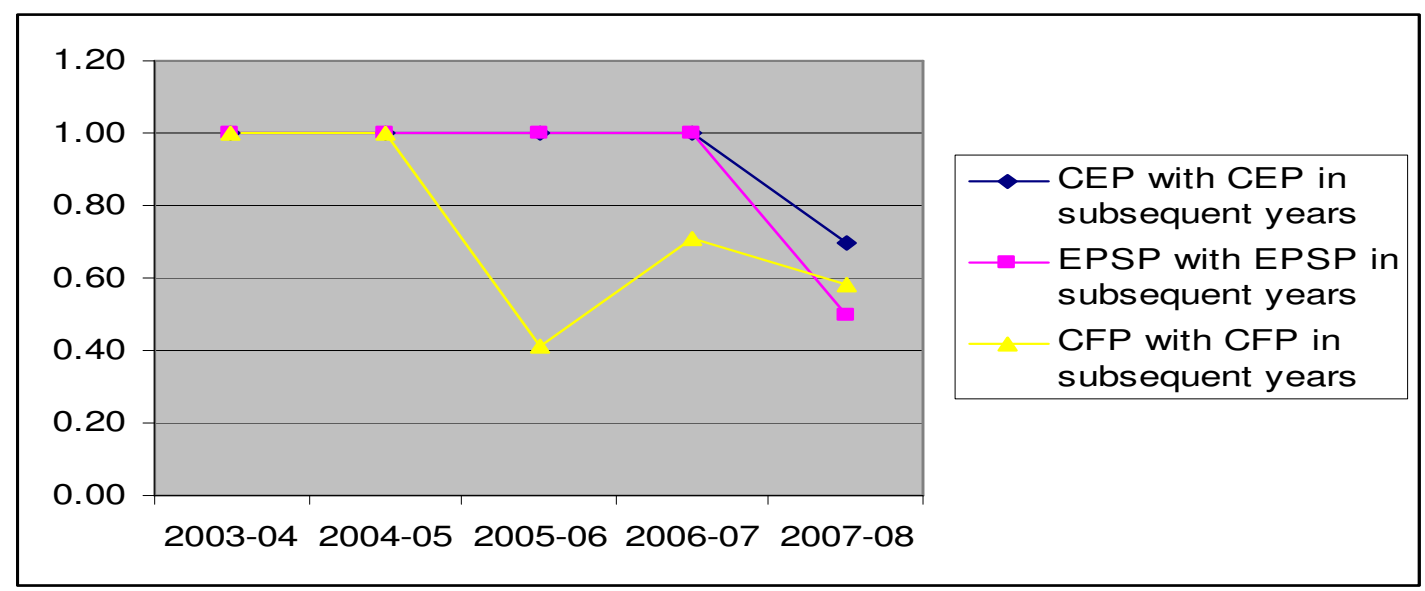

The median correlation of the CEP numbers shown in Table 1 (Appendix II) remains same at 1.00 for next three years after formation. In the last year, it decreases to 0.70 . Also, its correlation has been significantly high at 0.01 and 0.05 levels respectively, which again verifies the fact of persistency.

The median correlation of the EPSP numbers shown in Table 2 (Appendix II) remains same at 1.00 for next three years after formation. In the last year, it decreases to 0.50 . Like CEP, its correlation has also been significantly high at 0.01 and 0.05 levels respectively, which verifies persistency.

The median correlation of the CFP numbers shown in Table 3 (Appendix II) shows a fluctuating trend as compared to other variables. It remains at 1.00 for next year after formation. Then, it decrease from 1.00 to 0.41 in 2005-06, increases to 0.71 in 2006-07 and then again decreases to 0.58 in the last year of formation (2007-08). The degree of correlation is comparatively low. So, it shows less persistency.

The results show a good persistency in the EPSP and CEP numbers and a low persistency in the CFP numbers. Again the main question refers to the possible reason(s) that the persistence of the income statement -oriented (EPSP) and balance sheet-oriented (CEP) accrual numbers exceed that of the cash-flow accounting-based number (CFP). The two reasons given for the variability results may apply to the persistence results, namely, the income smoothing hypothesis and the selective market response hypothesis.

The high variability of CFP, as shown in the preceding discussion, is further verified by the median rank correlation here. The accrual based indicators, i.e. EPSP and CEP have shown less variability and high degree of persistency. So, the market response is more favorable for accrual-based indicators.

\section{Conclusion}

The key characteristic of finance function is the stewardship function. Financial statements help the evaluation of management's stewardship to the end-users. It is obvious that the accrual system finds a favour for reporting as compared to others on account of this fact. There was a definite difference in the variability of the accounting indicators of the sample 
companies, viz. the cash flow per share/stock price (CFP), the common equity per share/stock price (CEP), and the earnings per share/stock price (EPSP). The variability of the CFP numbers exceeded the variability of the CEP and EPSP numbers in seven cases. The variability of the CEP numbers was higher than those of the EPSP and CFP numbers in three cases. The variability of the EPSP numbers was higher than those of the CEP and CFP numbers in only two cases. The variability of CFP number exceeded the variability of CEP and EPSP numbers, both in degree and number of companies.

So, cash based indicators showed more variability than accrual based indicators. This indicates market preferences for accrual based indicators in pricing of securities. Further, EPSP shows the earning potential of the company and the earnings management is easier and more lucrative with income figures than cash-flow accounting data. As a result, EPSP finds a favour from the market.

But in spite of the differences in the variability of EPSP, CEP, and CFP numbers, a significant relationship is found between them, as clear in rank correlation results. It brings out that all these indicators influence each other directly or indirectly in stock pricing.

The persistency of the derived accounting indicator numbers was determined by examining the median rank correlation between the accounting indicator number in the year of formation and the same number in later years. The results show a good persistency in the EPSP and CEP numbers and a low persistency in the CFP numbers. It again verifies the persistency of the income statement -oriented (EPSP) and balance sheet-oriented (CEP) accrual numbers than of the cash-flow accounting-based numbers (CFP).

It is clear that the income statement-oriented and balance sheet-oriented accrual accounting-based numbers showed a lower variability and a higher persistence than the cash-flow accounting-based numbers. So, it can be inferred that stock market signals more favourably to accrual numbers than cash-based numbers. Since, companies are governed strongly by stock market motivations therefore they tend to follow accrual accounting for exercising earnings management choices. The results are consistent with earlier research on quality of earnings (Goel, 2014). Thus, it calls for an effective forensic audit regulation for the stakeholders' interests at large

\section{LIMITATIONS OF THE STUDY}

There are some limitations of this study which could be categorized as under:

The present study could be confined to only top twelve profit-making corporate enterprises in the private sector in India out of selected 25 enterprises, leaving all other enterprises due to data non-availability. The PSUs and banks \& financial institutions had to be excluded due to their distinct regulatory mechanism. Though the selected companies constitute a significant size of BSE's market capitalization for completeness of data, still the size can be extended for further study with regard to country -level results and global outreach for earnings management.

The time period in the study is of five years (2003-4 to 2007-08) to highlight earnings management motivation. This period is best suited to show the effects of global recession on the practice of earnings management in India. Researchers may like to select a different 
time-period based on their perspective.

Earnings management scope can be further examined, apart from stock pricing behaviour, for other motivational parameters in the light of growing investors' awareness about accrual reported numbers.

\section{Implications for Future Research}

The findings of this study are important to standard setters and regulators as the sample companies are constituent of BSE's Sensex. It highlights the need for an effective regulation for detecting earnings management. There is a strong need to have well-defined policies and regulatory mechanism with respect to prevent and detect earnings management practices at an early stage

Standard-setting bodies can consider the attributes of assets and liabilities and changes in them also with the fundamental process of measurement of income. In short, the evidence argues for a revenue/expense and asset/liability view of earnings, rather than the cash-flow view of earnings.

The findings of this study are significant not only for organisations that function in India but also for other companies globally as the sample companies are multinationals.

\section{References}

American Accounting Association. (1969). Committee on External Reporting. An Evaluation of External Reporting Practices. A Report of the 1966-68 Committee on External Reporting, The Accounting Review (Supplement), pp. 79-123.

Ashton, R. (1976). Cash Flow Accounting: A Review and Critique, Journal of Business Finance and Accounting (Winter), pp. 63-81. http://dx.doi.org/10.1111/j.1468-5957.1976.tb00693.x

Badertscher, B.A. (2011). Overvaluation and the Choice of Alternative Earnings Management Mechanisms, The Accounting Review, 86 (5), 1491-1518. http://dx.doi.org/10.2308/accr-10092

Baker, T., Collins, D., \& Reitenga, A. (2003). Stock Option Compensation and Earnings Management incentives, Journal of Accounting, Auditing and Finance, $18(4), 557-582$

Ball, R., Shivakumar, L. (2008). Earnings quality at initial public offerings, Journal of Accounting and Economics 45, 324-349. http://dx.doi.org/10.1016/j.jacceco.2007.12.001

Barley, B., and H. Levy. (1979). On the Variability of Accounting Income Numbers, Journal of Accounting Research (Autumn), pp. 305-315. http://dx.doi.org/10.2307/2490506

Barnea, A., J. Ronen, S. Sadan. (1976). Classificatory smoothing of income with extraordinary items, Accounting Review 51,110-122.

Barton. A.D. (1974). Expectations and achievements in income theory, The Accounting Review (October): 664-681.

Bartov, E. \& Mohanram, P. (2004). Private Information, Earnings Manipulations, and Executive Stock- Option Exercises, The Accounting Review, 79, 889-920 http://dx.doi.org/10.2308/accr.2004.79.4.889 
Beaver, W., C. Eger, S. Ryan, and M. Wolfson. (1989). Financial reporting, supplemental disclosures and bank share prices, Journal of Accounting Research (Autumn): 157-178. http://dx.doi.org/10.2307/2491230

Beneish, M. D. (1997). Detecting GAAP violation: Implications for assessing earnings management among firms with extreme financial performance, Journal of Accounting and Public Policy 16: 271-309.

--------------. (1998). Discussion of: Are accruals during initial public offerings opportunistic? Review of Accounting Studies 3: 209-221.

--.(2001).Earnings Management: A Perspective, Managerial Finance, Emerald Group Publishing Limited, Vol.27, No.12. http://dx.doi.org/10.1016/S0278-4254(97)00023-9

Beneish, M.,D. \& Vargus, M.E. (2002). Insider Trading, Earnings Quality and Accrual Mispricing, The Accounting Review, 77(4), 755-791. http://dx.doi.org/10.2308/accr.2002.77.4.755

Billing, M. B., Lewis, M.F.(2010). Opportunism and the related consequences in the IPO setting, Working paper, New York University.

Burgstahler, D., and I. Dichev. (1997). Earnings management to avoid earnings decreases and losses, Journal of Accounting and Economics, University of Washington, Vol. 24, No. 1.: 99-126. (1998). Incentives to manage earnings to

avoid earnings decreases and losses: Evidence from quarterly earnings,

Working paper, University of Washington.

------------, and M. Eames. (1998). Management of earnings and

analysts forecasts, Working paper, University of Washington.

Campa, D., and Camacho-Miñano, M.M. (2015). The impact of SME's pre-bankruptcy financial distress on earnings management tools, International Review of Financial Analysis, 42, 222-234. http://dx.doi.org/10.1016/j.irfa.2015.07.004

Cheng, Q., Warfield, T.D. (2005). Equity Incentives and Earnings Management, The Accounting Review, 80(2),441-476

http://dx.doi.org/10.2308/accr.2005.80.2.441

Cohen, D. A., Dey, A., \& Lys, T. (2008). Real and accrual-based earnings management in the pre- and post-sarbanes-oxley periods, The Accounting Review, 83(3), 757-787. http://dx.doi.org/10.2308/accr.2008.83.3.757

Cohen, D.A., Zarowin, P. (2010). Accrual-based and real earnings management activities around seasonal equity offerings, Journal of Accounting and Economics 50: 2-19. http://dx.doi.org/10.1016/j.jacceco.2010.01.002

Collins, D.W., and S.P. Hribar. (1999). Errors in Estimating Accruals: Implications for Empirical Research, Working Paper, University of Iowa.

Darrough, M., Rangan, S., (2005). Do insiders manipulate earnings when they sell their shares in an initial public offering? Journal of Accounting Research 43, 133. http://dx.doi.org/10.1111/j.1475-679x.2004.00161.x

DeAngelo E., H. DeAngelo, and D. Skinner. (1994). Accounting choices of troubled companies, Journal of Accounting and Economics 17 (January): 113-143. http://dx.doi.org/10.1016/0165-4101(94)90007-8

De Angelo, L., (1986). Accounting numbers as market valuation substitutes: A study of management buyouts of public stockholders, The Accounting Review,61. 400-420.

DeAngelo, L. E. (1988). Managerial competition, information costs, and corporate governance: The use of accounting performance measures in 
proxy contests, Journal of Accounting and Economics 10: 3-36. http://dx.doi.org/10.1016/0165-4101(88)90021-3

Dechow, P.M. (1994). Accounting earnings and cash flow as measures of firm performance: The role of accounting accruals, Journal of Accounting and Economics 17: 3-42. http://dx.doi.org/10.1016/0165-4101(94)90016-7

, and R.G. Sloan.(1991). Executive incentives and the horizon problem: An empirical investigation, Journal of Accounting and Economics 14: 5189. http://dx.doi.org/10.1016/0167-7187(91)90058-S

(1996). Causes and

consequences of earnings manipulation: An analysis of firms subject to enforcement actions by the SEC, Contemporary Accounting Research 13

(1): 1-36.

and (1995). Detecting earnings

Management, The Accounting Review, 70(2), 193-225.

Dechow, P. M , R.G. Sloan and A.P. Hutton.(1996). Causes and Consequences of Earnings Manipulation: An Analysis of Firms Subject to Enforcement Actions by the SEC, Contemporary Accounting Research, Vol. 13, No. 2. Spring. http://dx.doi.org/10.1111/j.1911-3846.1996.tb00489.x

Dechow, P. M. and C.M. Schrand. (2004). Earnings Quality, Research Foundation of CFA Institute Monograph.

D.J. Skinner. (2000). Earnings management: Reconciling the views of accounting academics, practitioners, and regulators, Accounting Horizons 14,235-250. http://dx.doi.org/10.2308/acch.2000.14.2.235

and J. Jiambalvo. (1994). Debt covenant effects and the manipulation of accruals, Journal of Accounting and Economics 17 (January): 145-176.

DuCharme, L.L., Malatesta, P.H., Sefcik, S.E. (2001). Earnings management: IPO valuation and subsequent performance, Journal of Accounting, Auditing \& Finance 16, 269-296.

Economic Times Survey. (2007). The Economic Times, October, New Delhi, India.

García Lara, J. M., García Osma, B., and Mora, A. (2005). The effect of earnings management on the asymmetric timeliness of earnings, Journal of Business Finance \& Accounting,32(3-4), 691-726. http://dx.doi.org/10.1111/j.0306-686X.2005.00610.x

Glover Jonathan, etal.(1998) .Earnings Management and the Revelation Principle, Review of Accounting Studies, Springer Science + Business Media B.V., Vol.3, No.1-2.

Goel, Sandeep. (2012). Demystifying earnings management through accruals management: An Indian Corporate Study, Vikalpa, IIM Ahemadabad, India.

Goel, Sandeep. (2014). The quality of reported numbers by the management: A Case Testing of Earnings Management in Corporate India, Journal of Financial Crime, 21,3: 355-376. http://dx.doi.org/10.1108/JFC-02-2013-0011

Graham, J. R., Harvey, C. R., \& Rajgopal, S. (2005). The economic implications of corporate financial reporting, Journal of Accounting and Economics, 40(1), 3-73. http://dx.doi.org/10.1016/j.jacceco.2005.01.002

Hanna, J.R. (1974). Accounting Income Models: An Application and Evaluation. Special Study No. 8. Toronto: Society of Management Accountants.

Healy, P.M. (1985). The effect of bonus schemes on accounting decisions,

Journal of Accounting and Economics 7: 85-107.

http://dx.doi.org/10.1016/0165-4101(85)90029-1 
and K. G. Palepu. (1990). Effectiveness of accounting-based dividend covenants, Journal of Accounting and Economics 12 (1-3): 97-124. http://dx.doi.org/10.1016/0165-4101(90)90043-4

and J.M. Wahlen.(1999). A review of the earnings management literature and its implications for Standard Setting, Accounting Horizons 4,368; 13,365.

S. Kang, and K. Palepu. (1987). The effect of accounting procedure changes on CEOs' cash salary and bonus compensation, Journal of Accounting and Economics 9: 7-34. http://dx.doi.org/10.1016/0165-4101(87)90015-2

Hicks, B.E. (1980). The Cash Flow Basis of Accounting, Working Paper No. 13.Sudbury, Ontario: Laurentian University.

Hirst, D. E., and P. E. Hopkins. (1998). Comprehensive income reporting and analysts' valuation judgments, Journal of Accounting Research (Supplement): 47-75. http://dx.doi.org/10.2307/2491306

Ibrahim, S. S. (2009). The usefulness of measures of consistency of discretionary components of accruals in the detection of earnings management, Journal of Business Finance \& Accounting, 36(9-10), 1087-1116. http://dx.doi.org/10.1111/j.1468-5957.2009.02171.x

Imhoff, E.A.(1977).Income smoothing - a case for doubt, Accounting Journal Spring, 85100.

Jones, J. J. (1991). Earnings management during import relief investigations, Journal of Accounting Research 29: 193-228. http://dx.doi.org/10.2307/2491047

Kothari, S. P., Leone, A. J., and Wasley, C. E. (2005). Performance matched discretionary accrual measures, Journal of Accounting and Economics, 39(1),163-197. http://dx.doi.org/10.1016/j.jacceco.2004.11.002

Kwon, S.S. \& Yin, Q.J. (2006). Executive Compensation, Investment Opportunities and Earnings Management : High-Tech Firms Versus Low-Tech Firms, Journal of Accounting, Auditing and Finance, 21(2), 119-148

Lawson, G.H. (1971). Cash-Flow Accounting I \& II. Accountant (October 28 and November 4), pp. 20-31.

Leuz, C.,et al.(2003).Earnings management and investor protection: An international comparison, Journal of Financial Economics 69,505-527. http://dx.doi.org/10.1016/S0304-405X(03)00121-1

etal. (2003). Earnings Management and Investor Protection: An International Comparison, Journal of Financial Economics, 69.

McNichols, M., and P. Wilson. (1988). Evidence of earnings management

from the provision for bad debts, Journal of Accounting Research 26

(Supplement): 1-31. http://dx.doi.org/10.2307/2491176

Miller, Paul B.W. and Paul R. Bahnson. (2002). Quality Financial Reporting, New York: McGraw -Hill.

Modigliani, F.etal.(1958).The Cost of Capital, Corporation Finance and The Theory of Investment, American Economic Review, Vol. 48, June.

P.N. Healy and J.N. Wahlen.(1999). A Review of the Earnings Management Literature and Its Implications for Standard Setting, Accounting Horizons 4, p. 368. http://dx.doi.org/10.2139/ssrn.156445

Park, M.S. \& Park, T. (2004). Insider sales and earnings management, Journal of Accounting and Public Policy, 23(5),381-411. http://dx.doi.org/10.1016/j.jaccpubpol.2004.07.003

Pathak, J., Karim, K., Suh, S. and Zhang, Z. 2014, 'Do audit committee and characteristics of board of Directors Influence Earnings Management?', Working Paper. 
Peasnell, K.V., P. F. Pope, and S. Young. (1999). Outside directors, board effectiveness, and abnormal accruals, Working paper, Lancaster University.

etal.(2000).Accrual Management To Meet Earnings Targets: UK Evidence Pre-and Post-Cadbury, The British Accounting Review, Academic Press, December, Vol.32, No.4, pp. 415-445(31).

Ronen, J., and S. Sadan. (1981). Smoothing Income Numbers: Objectives, Means and Implications, Reading, MA: Addison-Wesley.

Rugman, A.M. (1980). Internalization as a general theory of foreign direct investment: A reappraisal of the literature, Journal of Economic Literature 116: 365-375.

Schipper, K. (1989). Commentary: Earnings management, Accounting

Horizons (December): 91-102.

Scholes, M., G. P. Wilson, and M. Wolfson. (1990). Tax planning, regulatory capital planning, and financial reporting strategy for commercial banks, Review of Financial Studies 3: 625-650. http://dx.doi.org/10.1093/rfs/3.4.625

Scott, W.R. (2009). Financial accounting theory. Fifth ed. Prentice Hall, Upper Saddle River, New Jersey.

Stolowy, Herve ,Gaetan. Breton. (2000). A Review of Research on Accounts Manipulation. Presented at the $23^{\text {rd }}$ Annual Congress of the European Accounting Association, Munich, Germany, March 29-31.

Stolowy, H., G. Breton. (2004). Accounts manipulation: A Literature Review and Proposed Conceptual Framework, Review of accounting and Finance3,565. http://dx.doi.org/10.1108/eb043395

Teoh, S. H., I. Welch, and T. J. Wong. (1998a). Earnings management and the post-issue performance of seasoned equity offerings, Journal of

Financial Economics (October) 50: 63-99.

http://dx.doi.org/10.1016/S0304-405X(98)00032-4

----------, ----------, and -----------. (1998b). Earnings management and the longterm market performance of initial public offerings, Journal of Finance (December) 53: 1935-1974.

T. J. Wong, and G. Rao. (1998). Are accruals during initial

public offerings opportunistic? Review of Accounting Studies 3, pp.173-208.

Warfield, T.D., J.J. Wild, and K.L. Wild. (1997). Managerial ownership, accounting choices, and informativeness of earnings, Journal of Accounting and Economics 20,61-91. http://dx.doi.org/10.1016/0165-4101(94)00393-J

Watts, R. L., and Zimmerman, J. L. (1978). Towards a positive theory of the determination of accounting standards, The Accounting Review,53(1), 112134.

Wilson, P. (1986). The Relative Information Content of Accruals and Cash Flows: Combined Evidence at the Earnings Announcement and Annual Report Release Date, Journal of Accounting Research (September), 165-200. http://dx.doi.org/10.2307/2490736

Xie, H. (1998). Are discretionary accruals mispriced? A re-examination, Unpublished dissertation, University of Iowa.

Zang, Amy Y. (2011). Evidence on the Tradeoff between Real Manipulation and Accrual Manipulation, The Accounting Review, 87 (2), 675-703. http://dx.doi.org/10.2308/accr-10196 


\section{Appendix I}

Index of Companies Included in the Study

\begin{tabular}{|l|l|l|}
\hline S.NO. & \multicolumn{1}{|c|}{ COMPANY } & \multicolumn{1}{|c|}{$\begin{array}{c}\text { PAT (2007) } \\
\text { Rs. Crore }\end{array}$} \\
\hline 1. & Reliance Industries Ltd. & 12,075 \\
\hline 2. & Sterlite Industries Ltd. & 4,386 \\
\hline 3. & Tata Consultancy Services Ltd. & 4,213 \\
\hline 4. & Tata Steel Ltd. & 4,177 \\
\hline 5. & Bharti Airtel Ltd. & 4,062 \\
\hline 6. & Infosys Technologies Ltd. & 3,856 \\
\hline 7. & Wipro Ltd. & 2,942 \\
\hline 8. & ITC Ltd. & 2,755 \\
\hline 9. & Hindalco Ltd. & 2,687 \\
\hline 10. & Larsen and Toubro Ltd. & 2,251 \\
\hline 11. & Tata Motors Ltd. & 2,170 \\
\hline 12. & Grasim Industries Ltd. & 1,968 \\
\hline
\end{tabular}

Source: ET 500, The Economic Times, New Delhi, October, 2007. 


\section{Appendix II}

Rank Correlation of Companies' Accounting Indices

Table 1

Rank Correlations of All the Sample Companies' CEPs with CEPs in Subsequent Years, 2003-04 to 2007-08

\begin{tabular}{|l|l|l|l|l|l|}
\hline \multirow{3}{*}{ Base Year } & \multicolumn{5}{|c|}{ Years Following Base Year } \\
\cline { 2 - 7 } & $\mathbf{1}$ & $\mathbf{2}$ & $\mathbf{3}$ & $\mathbf{4}$ & $\mathbf{5}$ \\
\hline $2003-04$ & 1.00 & 0.91 & 0.86 & 0.70 & 0.39 \\
\hline $2004-05$ & & 1.00 & 0.97 & 0.87 & 0.70 \\
\hline $2005-06$ & & & 1.00 & 0.93 & 0.72 \\
\hline $2006-07$ & & & & 1.00 & 0.82 \\
\hline $2007-08$ & & & & & 1.00 \\
\hline $\begin{array}{l}\text { Median } \\
\text { Correlation }\end{array}$ & 1.00 & 1.00 & 1.00 & 1.00 & 0.70 \\
\hline
\end{tabular}

Table 2

Rank Correlations of All the Sample Companies' EPSPs with EPSPs in Subsequent Years, 2003-04 to 2007-08

\begin{tabular}{|l|l|l|l|l|l|}
\hline \multirow{2}{*}{ Base Year } & \multicolumn{5}{|c|}{ Years Following Base Year } \\
\cline { 2 - 6 } & $\mathbf{1}$ & $\mathbf{2}$ & $\mathbf{3}$ & $\mathbf{4}$ & $\mathbf{5}$ \\
\hline $2003-04$ & 1.00 & 0.89 & 0.70 & 0.67 & 0.46 \\
\hline $2004-05$ & & 1.00 & 0.82 & 0.80 & 0.50 \\
\hline $2005-06$ & & & 1.00 & 0.89 & 0.82 \\
\hline $2006-07$ & & & & 1.00 & 0.80 \\
\hline $2007-08$ & & & & & 1.00 \\
\hline $\begin{array}{l}\text { Median } \\
\text { Correlation }\end{array}$ & 1.00 & 1.00 & 1.00 & 1.00 & 0.50 \\
\hline
\end{tabular}

Table 3

Rank Correlations of All the Sample Companies' CFPs with CFPs in Subsequent Years, 2003-04 to 207-08

\begin{tabular}{|l|l|l|l|l|l|}
\hline \multirow{2}{*}{ Base Year } & \multicolumn{6}{|c|}{ Years Following Base Year } \\
\cline { 2 - 7 } & $\mathbf{1}$ & $\mathbf{2}$ & $\mathbf{3}$ & $\mathbf{4}$ & $\mathbf{5}$ \\
\hline $2003-04$ & 1.00 & 0.66 & 0.33 & 0.65 & 0.65 \\
\hline $2004-05$ & & 1.00 & 0.41 & 0.88 & 0.68 \\
\hline $2005-06$ & & & 1.00 & 0.41 & 0.16 \\
\hline $2006-07$ & & & & 1.00 & 0.75 \\
\hline $2007-08$ & & & & & 1.00 \\
\hline $\begin{array}{l}\text { Median } \\
\text { Correlation }\end{array}$ & 1.00 & 1.00 & 0.41 & 0.71 & 0.58 \\
\hline
\end{tabular}

